\title{
Del thriller a la acción: la ciudad de Sevilla como plató cinematográfico
}

Funciones y localizaciones de la urbe en tres relatos fílmicos.

Mónica Tovar Vicente y María José Bogas Ríos

\section{OpenEdition}

Journals

Edición electrónica

URL: http://journals.openedition.org/agedor/1771

DOI: 10.4000/agedor.1771

ISSN: 2104-3353

Editor

Laboratoire LISAA

Referencia electrónica

Mónica Tovar Vicente y María José Bogas Ríos, « Del thriller a la acción: la ciudad de Sevilla como plató cinematográfico », L'Âge d'or [En línea], 10 | 2017, Publicado el 17 enero 2019, consultado el 21 diciembre 2020. URL : http://journals.openedition.org/agedor/1771 ; DOI : https://doi.org/10.4000/ agedor.1771

Este documento fue generado automáticamente el 21 diciembre 2020.

L'Âge d'or. Images dans le monde ibérique et ibéricoaméricain 


\section{Del thriller a la acción: la ciudad de Sevilla como plató cinematográfico}

Funciones y localizaciones de la urbe en tres relatos fílmicos.

Mónica Tovar Vicente y María José Bogas Ríos

1 En la historia de la construcción de la imagen de España a través de las artes, Sevilla, junto a Madrid, ocupa un lugar predominante en el imaginario colectivo. Movimientos como el Romanticismo o el Costumbrismo poseen como principio la nostalgia por épocas pasadas donde aún no se había experimentado la influencia de la Modernidad, por lo que sientan sus bases en una relativa preservación de la tradición y lo primigenio y puro de los pueblos y culturas que aún no habían sido alterados por los adelantos tecnológicos ni por la Revolución Industrial, contraponiéndolos a los intereses modernistas y racionalistas imperantes. Así, España se convierte en el siglo XIX en un lugar exótico de visita obligada dado su retraso evolutivo con respecto a otros países europeos, el carácter multicultural de su población y un pasado árabe y judío que parecen convertirlo en un Oriente cercano. Será en este momento cuando se inicie una relación estrecha entre su imagen y el incipiente turismo continental asociado, en sus orígenes, a las clases altas e intelectuales. Por su parte, el mantenimiento reforzado de determinados rasgos de la metrópoli ha promovido la aparición de una Sevilla estereotipada que, igualmente, ha encontrado en el cine a otra de sus vías comunicativas, si bien, determinada por la visión e interpretación de los guionistas y directores que han ubicado sus relatos en sus dimensiones urbanas.

2 Ahora bien, estas individualidades apreciativas no siempre han implicado un distanciamiento en términos manifestantes y significativos justificado, en parte, por la propia valoración y puesta en escena que hace la ciudad de sí misma. En los diferentes apartados de este artículo, profundizamos en el proceso creativo e instaurador de la imagen de la urbe sevillana llegando a tres casos fílmicos que examinamos con la finalidad de identificar las similitudes y diferencias en términos narrativos y visuales; a su vez, el hecho de que hayan sido producidos en diferentes años y países permite aplicar un principio interpretativo asociado a la conceptualización que se tiene de la ciudad española tanto dentro como fuera de sus límites nacionalmente geográficos. De este 
modo, la norteamericana Noche y día (James Mangold, 2010), la noruega La Joven de las naranjas (Eva Dahr, 2009) y la española Nadie conoce a nadie (Mateo Gil, 1999) muestran a una capital específica a la par que común ofreciéndole intrínsecamente al espectador recorridos que le permiten reavivar la experiencia cinematográfica; un empleo derivado del texto fílmico al que ha recurrido asimismo la página web de turismo oficial de la metrópoli andaluza.

\section{Breve historia de una imagen: la conceptualización visual y artística de Sevilla}

3 La vinculación entre el turismo y la imagen se define por un carácter arraigado en la tradición de los libros de viajes en los cuales los visitantes relataban su experiencia acompañada de ilustraciones y grabados de los lugares por los que pasaban recreando la experiencia que, en ocasiones, era impuesta por las casas editoriales para los propios lectores de lo que se esperaban encontrar en el destino escogido ${ }^{1}$. Con la llegada del ferrocarril y de la fotografía, esta relación cobra nuevas dimensiones: el desplazamiento se configura como una "fantasía para el viajero" y la experiencia, en su constatación. Es en este doble sentido en el que actuarían las postales al fomentar un imaginario sobre el que las recibe y suponer una reafirmación del traslado para el que las envía ${ }^{2}$.

4 En el caso nacional y de forma específica para el territorio sevillano, el principal referente para los estudios sobre esta representación y consiguiente asociación es el autor Francisco Ayala y su obra La Imagen de España (1986). En ella y aludiendo a uno de aquellos viajeros ingleses que testimoniaron su paso por la península, $\mathrm{H}$. V. Morton, determina que "la España de cartel turístico nació en Sevilla durante el siglo XIX, y fue creada en gran medida por las clases ricas de Inglaterra que llegaban en barco a Cádiz o a Gibraltar"3. Sin embargo y según las consideraciones de José Luis Navarrete en sus trabajos Historia de un género cinematográfico: la españolada (2009) y La Españolada y Sevilla (2003), la generación de la idiosincrasia andaluza y, particularmente, sevillana se remonta al siglo XVI cuando autores nacionales empezaron a codificarla en el imaginario patrio a través de la novela, el teatro, la zarzuela o la pintura. Por tanto, un doble proceso distanciado en el tiempo y en la perspectiva aplicada que, por el contrario, no ha originado una dualidad apreciativa y sí un reforzamiento de las imágenes expresivas. A ello se suma que dos de los grandes mitos asociados a lo español y convertidos en arquetipos universales tienen lugar en la urbe hispalense: Carmen, más en su versión operística realizada por Georges Bizet que en la obra de Prosper Mérimée, hija del exotismo romántico decimonónico; y la figura del Don Juan, tanto en la obra de Tirso de Molina, El Burlador de Sevilla (1630), como en el Don Juan Tenorio de José Zorrilla (1844), heredero del pensamiento de la contrarreforma religiosa del siglo XVII. En este sentido, el reconocimiento adquirido por el mito de Carmen supuso una suerte de descontento entre los intelectuales europeos que incluían en sus rutas al sur español: como recoge Serafín Fanjul, atraídos por la ambientación oriental del gusto romántico, llegaban a incluir dentro del arabismo arquitectónico elementos como las estructuras de las casas sevillanas (con un patio central de clara herencia romana) que no coincidían con sus manifestaciones reales ${ }^{4}$. Ahora bien, este proceso continuado y potenciador que construye la imagen de la ciudad de Sevilla se define por ser anterior al nacimiento del cinematógrafo; es decir, si el invento de los hermanos Lumière es considerado uno de los recursos más efectivos para la construcción y el mantenimiento del imaginario colectivo urbano, cuando su uso empieza a ser una 
práctica comercial, la capital hispalense ya donaba per se una identidad definida a los camarógrafos interesados en retratarla: su carácter monumental, junto a su pasado árabe, judío y cristiano, así como el hecho de ser una de las ciudades más relevantes del período colonial e imperialista español, revisten a la urbe de un halo de exotismo y misterio donde las cigarreras, los contrabandistas y los toreros se daban la mano en historias amorosas y trágicas en las que aparecía como telón de fondo.

Una vez establecida su identidad imaginada, el siglo XX se entiende como un período en el que Sevilla asume la condición de ciudad turística representativa del marco nacional y comprende los efectos beneficiosos que el séptimo arte podía tener para su manifestación. Así, Antonia Rey-Reguillo recoge en su libro Cine, imaginario y turismo cómo el cartel turístico español nace en Andalucía y cómo el régimen dictatorial de Primo de Rivera y la Exposición Hispano-Americana de 1929 fortalecen las relaciones entre el cine, el turismo y la urbe hispalense iniciadas pocos años antes y es que, si en décadas previas había quedado patente que "ese cine de los orígenes ya apuntaba a la capacidad del medio fílmico para construir realidades autónomas capaces de modular ideas preconcebidas sobre lo visible tras las cuales lo real queda solapado"5; a lo largo de la etapa citada, se pensará en el séptimo arte como el vehículo para promocionar la imagen del país. El efecto no será muy diferente al propiciado por la literatura y la música en los siglos anteriores, ya que, la propaganda turística recurre al lenguaje audiovisual dada su "capacidad para mitificar escenarios naturales"; esto es, los lugares retratados en un film aparecían en el imaginario del potencial visitante como espacios ideales, desrealizando el mundo que, mediante el filtro de las imágenes, se convierte en un "espectáculo artificioso y casi ajeno a su propia naturaleza" ámbito político toma conciencia del poder del medio cinematográfico tanto para crear y fomentar una imagen de España como impulsar medidas heredadas de legislaturas anteriores, lo hace basándose en la idea de modificar al estereotipo de la españolada que relegaba al país a las regiones rurales y menos desarrolladas del mismo, a esa Andalucía latifundista "poblada de gitanos y toreros, con criterios atávicos, reaccionarios y machistas". Una imagen que gran parte de la crítica fílmica se empeñaba en calificar como falsa ya desde la década de los diez y que continuará durante la II República y el Régimen franquista, a la par que demandaba una producción patria que ensalzara lo verdaderamente nacional sin los aspectos folcloristas y carpetovetónicos del mismo9.

Con motivo de mostrar a ese país modernizado y alejado de los estereotipos atribuidos, España realiza las exposiciones Internacional de Barcelona y la Hispano-Americana de Sevilla, ambas en 1929, y pone en marcha la Red Nacional de Paradores y el Patronato Nacional de Turismo que sustituye a la Comisaría Regia del Turismo dotándola de mayores recursos económicos y competencias. Al mismo tiempo, el evento hispalense es comprendido como un motivo justificado para introducir cambios en el trazado urbano y arquitectónico de la metrópoli; de este manera, se remodeló parte del Casco Antiguo con los ensanches en el Barrio de Santa Cruz y la incorporación de los terrenos de los Alcázares previamente cedidos por Alfonso XIII; se crearon barrios como el de Heliópolis, Ciudad Jardín (para alojar a los visitantes de la exposición) y el de El Porvenir, con chalés para la burguesía y la clase social alta. También se procedió al ensanche y urbanización de la Avenida de la Palmera y la creación de los pabellones Mudéjar y de las Bellas Artes en la Plaza de América, como también se desarrolló el proyecto más ambicioso de toda la exposición, la Plaza de España; estas últimas acciones a cargo del arquitecto Aníbal González considerado uno de los artífices del regionalismo andaluz de corte historicista y 
costumbrista. Otros edificios heredados de esta gran remodelación urbanística son el Casino, el Coliseo Español o la Puerta de Jerez.

7 El otro gran hito que modificará el diseño metropolitano será la Exposición Universal de 1992, coincidente con el V centenario del descubrimiento de América, la cual supuso una modernización con respecto a las infraestructuras dadas la creación de una nueva estación de ferrocarril y la adecuación de las vías para el tren de alta velocidad AVE, la ampliación del aeropuerto, la implantación de circunvalaciones y la construcción de puentes como el del V Centenario, el del Alamillo o el de Barqueta que dan acceso al recinto de la Cartuja, lugar elegido para el emplazamiento de los pabellones. Sendos procesos, distanciados en el tiempo y promovidos por diferentes ideales políticos, manifiestan el interés por hacer de Sevilla una metrópoli contemporánea capaz de adaptarse y actualizarse aunque sin despojarse de muchos de esos rasgos estereotípicos mantenidos durante todos estos siglos. La cuestión es, por tanto, vislumbrar el proceso y los métodos por los que la ciudad reduce el impacto de lo reconocido y lo reconocible en aras a propiciar un equilibrio con lo desconocido y autóctono en su concepción más primigenia y atemporal.

\section{La mirada del cine: una revisión de la expresión y representación de la urbe hispalense}

8 Como apuntábamos, las imágenes de viajes serán uno de los géneros más explotados en las primeras casas cinematográficas pudiendo encontrarlas en los catálogos de los Lumière, Gaumont o Paul/Short. En el caso de la capital hispalense, tres serán los temas más retratados: "las imágenes de monumentos, las de tipos humanos y las tauromaquias" ${ }^{10}$. En términos de exhibición, Begoña Soto presenta en su trabajo de 2007 una consideración relevante y es que, en el caso de los Lumière, el tratamiento narrativo y fílmico que hacían de la metrópoli se definía no solo por expresar una mirada extranjera, también porque los espectadores no eran los españoles. Esto es, esas piezas estaban destinadas a un público ajeno a la realidad urbana y arquitectónica incurriendo en la repetición de imágenes preconcebidas: fiestas populares y folclóricas (religiosas y laicas), bailes típicos, un mercadillo al aire libre presentado como la Feria de abril o un coso taurino que, en lugar de ser el sevillano, parece corresponderse con el de la localidad francesa de Nimes ${ }^{11}$. Por su parte, las vistas que también recogería la realizadora Alice Guy para la Gaumont en 1905 obedecerían a este tipo de patrones: bailes como el bolero o el tango en la Casa de Pilatos y los danzarines con mantón y sombrero cordobés o los castizos con trajes de majos y majas o una panorámica del río Guadalquivir en la que se puede ver desde el puerto con el Puente de Isabel II hasta la Torre del Oro pasando por la fachada de la plaza de toros de la Real Maestranza ${ }^{12}$. Con respecto a la cinematografía española, la inclusión de Andalucía en este tipo de género es escasa y no será hasta la década de los diez cuando centre su mirada sobre la comunidad y más desde la ficción que desde el reportaje o el documental. No obstante, se identifican algunas excepciones previas como una grabación protagonizada por La Cofradía de la Macarena proyectada el 30 de marzo de 1899 en el Teatro Cervantes o una corrida de todos que fue rodada el 2 de abril ${ }^{13}$, aunque y en ambos casos, las tomas se encuentran mediatizadas por esa mirada local y costumbrista al estilo de los precedentes. 
9 Este prisma costumbrista será el que impere en el género de ficción durante gran parte del siglo identificándose un extenso número de producciones en las que Sevilla es escenario de historias de diversas características. A su vez, largometrajes como Currito de la Cruz (Fernando Delgado y Alejandro Pérez Lugín, 1925; Fernando Delgado, 1936), melodrama taurino basado en la obra teatral homónima del segundo autor indicado, desarrollan todos los temas y arquetipos basados en el costumbrismo español y que se repetirán en innumerables ocasiones: la orfandad, la honra y su contrario, la redención femenina mediante el matrimonio o la ascensión social gracias al éxito en una profesión de renombre, entre otros. Sin embargo y como señala Antonia Rey-Reguillo, la relación entre la trama narrativa y la metropolitana se definía por un desequilibrio favorable hacia la segunda, puesto que, "el envoltorio espacial del relato acaba robando el protagonismo a los sujetos que lo habitan [...] la estrella de este periplo no es otra que Andalucía y su epicentro, la ciudad de Sevilla, y, por transposición metonímica, la Giralda" ${ }^{14}$. Residen aquí dos aspectos en los que queremos profundizar dada su relevancia para la imagen que el séptimo arte ha ofrecido de la urbe hispalense.

10 El primero de ellos es el proceso por el que la torre campanario de la catedral sevillana pasa de una fase denominativa y localizadora protagonista a otra en la que son los referentes del imaginario andaluz los que permiten la ubicación geográfica del texto fílmico. De esta manera, mientras que, inicialmente, La Giralda es uno de los elementos iconográficos que se repetirán en decorados ambientados en la ciudad (como sucede con Sangre y arena, la película de 1922 dirigida por Fred Niblo, en la que su presencia en el tercer plano inicial permite el anclaje de la narración al territorio hispalense aun habiéndose rodado en estudios hollywoodienses); conforme se desarrolla el siglo XX, empiezan a distinguirse ópticas narrativas que resultan, como señala José Luis Navarrete, en la negación de estos elementos iconográficos, ya que, al tratarse de un nivel de codificación elevado, automáticamente, se enmarcan bajo la etiqueta de españolada ${ }^{15}$. La principal consecuencia de esta desaparición fue la dotación de relevancia a la ciudad per se, convertida en un quasi personaje de la historia y manifestada mediante la ambientación de estilo andaluz (casas de patios con flores y decoración árabe, tabernas, ventanas enrejadas), los personajes estereotípicos adscritos al imaginario de la urbe (toreros, gitanas, cantaores), la vestimenta o los temas tratados. A ello se suma la existencia de un star system que dota a la película de la presencia de la ciudad: las versiones mudas de Carmen, como la de Cecil B. DeMille en 1915 o su parodia realizada por Charles Chaplin en el mismo año, al igual que la versión de Florián Rey en 1938, Carmen la de Triana, realizada en los estudios de la UFA en Alemania, no necesitan de esta recreación, dado que, por el carácter de mito que posee la historia, no se hace realmente necesario mostrar a la ciudad. Sin embargo y en el caso de esta última, la artista Imperio Argentina declarará constantemente, a través de sus canciones y diálogos, la fidelidad y lealtad a la metrópoli dotándola, como decíamos, de una entidad casi de personaje ${ }^{16}$. Otros ejemplos de esta realidad significativa e identificativa se dan en Morena Clara (Florián Rey, 1936; Luis Lucía, 1954), El Barbero de Sevilla (Benito Perojo, 1938) o Mariquilla la Terremoto (Benito Perojo, 1938) y en las que la ambientación y alguna referencia realizada por los personajes son las que ubican geográficamente al film. Por su parte, en Suspiros de España (Benito Perojo, 1938) sí que aparecen elementos reconocibles como el Puente de Isabel II o, en el caso de Sucedió en Sevilla (José Gutiérrez Maesso, 1954), rodada en los exteriores de la ciudad y no en decorados como muchas de sus precedentes, la ribera del río aparece en momentos idílicos donde uno de los protagonistas masculinos declara su amor a Juanita 
Reina quien será engañada por el mismo, lo que lleva a otra cuestión muy reiterada en este tipo de cine: la relación entre el entorno urbano y la caída en desgracia de la joven protagonista y el entorno rural como deudor de la honra femenina.

11 El período en el que la disociación entre la urbe y sus iconos arquitectónicos se cumple efectivamente se inicia en el tercio final del siglo XX motivado por el auge del cine de las nacionalidades que se origina durante los últimos años del Régimen franquista $\mathrm{y}$, de forma notoria, tras su muerte. La producción fílmica empieza a descentralizarse y, en la comunidad andaluza, emerge un aparato industrial que reivindica su propia cultura regional y su realidad social tratando de alejarse de los estereotipos manidos de la españolada. De entre los títulos que participan de esta especie de corriente creativa y narrativa destacamos a Vivir en Sevilla (Gonzalo García Pelayo, 1978) en el que el director realiza un ejercicio de identidad recurriendo a tintes ensayísticos, mezcla de ficción y documental, tratando de reflejar a la ciudad tanto en sus elementos iconográficos como en su idiosincrasia, pero, incluyendo a los problemas sociales que la azotaban en ese momento. También, Solas (1999) de Benito Zambrano está protagonizado por una temática social en la que la recreación urbana es periférica sin contribuir elemento alguno a su reconocimiento (siendo identificable solo para aquellos que han transitado por esa zona alguna vez) o El Traje (2002) de Alberto Rodríguez en el que un inmigrante subsahariano trata de subsistir en una metrópoli que desconoce y que es mostrada como tal al espectador. Asimismo, producciones de género documental como Polígono Sur (Dominique Abel, 2003) posicionan a la cámara en uno de los barrios sevillanos más peligrosos y difíciles de retratar, las Tres Mil Viviendas. Esta pequeña selección ejemplifica la nueva perspectiva interpretativa y expresiva que ya no recrea la vitalidad ni la gracia andaluza anteriores, el cine ejerce como lienzo de una realidad social urbana definida por sus problemáticas (las drogas, el paro, la inmigración) y su constitución posmoderna (zonas marginales y barrios periféricos) que van más allá del reclamo de la postal de viajes abordada al inicio del texto.

Esta separación nos permite retomar el segundo aspecto en el que deseábamos ahondar y que no es otro que el gen de la españolada, un concepto que, en el ámbito del séptimo arte y para las piezas de ambiente andaluz, se define por una identidad sevillanocéntrica; es decir, la ciudad hispalense como telón de fondo inalterable. Ahora bien, este protagonismo responde, una vez más, a un principio de estatismo en tanto la metrópoli hispalense siempre ha ejercido como representante territorial tanto de la Comunidad Autónoma andaluza como del propio país, según venimos defendiendo. De esta forma y si se revisan las obras audiovisuales rodadas en sus dimensiones son pocas las que, durante el siglo XXI, han optado por otras provincias, si bien, pueden citarse Carceleras (José Buchs, 1922) grabada en Córdoba; La Lola se va a los puertos (Juan de Orduña, 1947), en Cádiz o Venta de Vargas (Enrique Cahen Salaberry, 1959), en Jaén. En gran parte, este continuismo queda justificado por la ausencia de alteración de la conceptualización de la españolada y es que no será hasta los años sesenta cuando adopte un nuevo sentido como respuesta al desgaste del musical folclórico predominante durante las décadas de los cuarenta y los cincuenta, fundamentalmente. Este género patrio tuvo un rol tan destacado para la Historia cinematográfica nacional que llegó a establecerse un sistema de artistas que necesitaba de la presencia de la ciudad para su significación completa: nombres como los de Angelillo, Imperio Argentina, Estrellita Castro, Manolo Escobar, Lola Flores, Antonio Molina o Carmen Sevilla figuraban en los créditos de las producciones en las que daban vida a andaluces que, en algún momento de sus carreras artísticas, 
interpretaron a sevillanos alegres y jacarandosos. Ahora bien, el desinterés incipiente hacia este tipo de historias se complementó con el boom turístico nacido en los sesenta fomentando esa relativa pérdida de los arquetipos sevillano y andaluz: las historias viran hacia la costa y, en lo concerniente a la región, la Costa del Sol, en la provincia de Málaga, se convertirá en la nueva localización predominante en la filmografía nacional ${ }^{17}$.

\section{El séptimo arte como experiencia turística: la ciudad sevillana como plató cinematográfico natural}

13 Los primeros estudios acerca del turismo inducido por el cine se remontan a la década de los setenta cuando Clare A. Gunn, a través de diversas investigaciones, determina que esta asociación se sustenta en imágenes preconcebidas; es decir, que "no reinventa un ideario nuevo sino que se apropia de aquellos elementos geográficos, culturales e históricos consolidados en el tiempo"18. Más recientemente, Alfonso Méndiz ha acuñado el término city placement, variante fílmica del product placement publicitario, $\mathrm{y}$ al que define como el

Emplazamiento de ciudades, regiones, monumentos, lugares turísticos y negocios de hospedaje y restauración en una producción audiovisual a cambio de una ayuda en la financiación, el rodaje o la promoción del filme, y con vistas a una promoción turística, a la mejora de su imagen en el exterior o a los beneficios económicos que cualquier rodaje comporta ${ }^{19}$.

14 En consecuencia, se aúnan la funcionalidad del séptimo arte como herramienta para incrementar el turismo en las ciudades que proyecta y el beneficio comercial común para sendas industrias. Este efectismo asociativo ha supuesto también la aparición de entidades como las Film office y las Film Commissions encargadas de facilitar y gestionar todos los recursos y permisos concernientes a los rodajes donde tienen sede, así como, creadoras de contenidos publicados en páginas webs oficiales y blogs que le otorgan al turista-espectador las indicaciones necesarias para visitar los escenarios naturales y arquitectónicos presentados en el montaje fílmico. Ahora bien, el impacto socioeconómico que el cine-turismo (concepto propuesto por Atout France, la agencia de desarrollo turístico del país galo) está teniendo para múltiples países ha propiciado que sus sitios webs empiecen a incluir secciones dedicadas a las presencias que la urbe ha tenido en piezas audiovisuales de diversa naturaleza (videoclips, anuncios publicitarios, corto y largometrajes); una especie de apropiación que manifiesta la aceptación de la identidad fílmica por la metrópoli. En el caso de la estudiada, esta condición queda evidenciada en la página visitasevilla.es cuya autoría es del Consorcio de Turismo. Su elección como recurso documental y referencial se ha debido, especialmente, al hecho de que nos interesa abordar el empleo que la ciudad hace de su condición cinematográfica para atraer a los visitantes e, igualmente, lo ha respaldado el hecho de que la información proporcionada por la Andalucía Film Commission responda a un principio general en el que todas sus regiones son abordadas de forma equilibrada. Sí deseamos hacer hincapié en la presencia de una pestaña en su diseño web denominada Cine y turismo y en la que ofrecen un listado de todas aquellas producciones filmadas en un mismo escenario y rutas de cine estructuradas a partir de determinadas películas, entre otros contenidos.

Regresando a visitasevilla.es, durante la elaboración de este texto (septiembre de 2017), su página principal incluía como segunda referencia a la entrada De 'Star Wars' a 'Juego de Tronos'. Siéntete un maestro Jedi, la Reina Amidala, Jaime Lannister o Khaleesi. En Sevilla puedes vivir un verdadero viaje de película. Del contenido, destacan algunos conceptos como que la 
ciudad es un plató natural, su presencia en producciones internacionales desde hace décadas y el incremento de visitas que ha sufrido desde su aparición en la citada serie de televisión. Sin embargo y a pesar de que se identifican otras alusiones al binomio cineciudad en el sitio web mencionado, es en su blog donde el turista-espectador encuentra la publicación Sevilla y sus escenarios de película; una relación de largometrajes y espacios urbanos y arquitectónicos que le ofrece la comentada posibilidad de experimentar in situ las vivencias protagonizadas previamente en el recuadro fílmico ${ }^{20}$. Esta enumeración (en cierto grado, sesgada al enunciar a un número contado de películas sin determinar motivo selectivo alguno) destaca por una doble diversidad: de años de producción (la primera referencia remonta a 1959 con La Femme et le pantin, dirigida por el francés Julien Duvivier; mientras que la última, diversificada en varios relatos, a 2011) y de nacionalidades (además de largometrajes españoles, los hay alemanes, ingleses, italianos y americanos); una heterogeneidad que refuerza el comentado atractivo que ostenta la ciudad hispalense como plató cinematográfico y su mantenimiento durante las últimas décadas, continuismo de la significación artística otorgada siglos atrás. Asimismo, el conjunto de los veintisiete escenarios sevillanos que aglutinan a las diferentes historias se define por recurrir a aquellos que ya habían asumido esta condición identificativa urbana en el pasado (el Real Alcázar, la Maestranza, la Catedral o el Patio de Banderas) y a esos otros que representan momentos históricos determinantes para el trazado urbano y su conformación (como la Plaza de España, los barrios de Santa Cruz y Triana o la estación de Sevilla-Santa Justa).

En lo concerniente a este trabajo y según hemos señalado, el blog de turismo oficial de la ciudad ha sido la referencia para la elección de los títulos examinados y cuyo análisis comparativo presentamos en los siguientes apartados. El principal criterio selectivo ha sido el número de presencias incluido en el listado; de esta manera, la producción noruega con participación sevillana ${ }^{21}$ La Joven de las naranjas es la más mencionada (en ocho ocasiones) seguida de Noche y día (seis enunciaciones) y de Nadie conoce a nadie (cuatro). En este sentido, debemos especificar que, en realidad, otras películas como Lifting de corazón (Eliseo Subiela, 2006), coproducción hispano-argentina, también estaban mencionadas cuatro veces, por lo que, aplicamos un segundo criterio en aras a trabajar con una muestra más pequeña que permitiera un estudio exhaustivo de cada uno de los textos fílmicos: que la película nacional se hubiera estrenado durante los últimos años del siglo XX con el objetivo de corroborar si, como hemos defendido, continuaba el principio de la negación de los iconos y estereotipos sevillanos ${ }^{22}$.

Otro motivo subyacente para estas elecciones fue el obtener una mirada diversificada de la urbe: eligiendo a una producción nacional; otra, europea y una norteamericana comprendíamos que el retrato que se obtiene de la ciudad hispalense queda determinado por la valoración e interpretación que determinados países y culturas han heredado y hacen de la metrópoli favoreciéndose la identificación de semejanzas y diferencias igualmente asociadas al tipo de producción. Con esto, lo que queremos decir es que el planteamiento narrativo del largometraje noruego responde a unos principios autorales alejados del concepto mainstream característico de los relatos hollywoodienses mientras que la película española no deja de apuntar a una imagen que se realiza dentro de los propios límites geográficos exponiendo la concepción que el español tiene del territorio al que pertenece $^{23}$. Una óptica tridimensional que, igualmente, se liga al proceso comunicativo del texto fílmico y a su funcionalidad significativa: el público que accede a Noche y día, internacional y constituido por un elevado número de espectadores, se aleja del perfil 
habitual del consumidor de cine europeo más específico y reducido, incluso especializado, mientras que, la producción española, en este caso concreto, se dirige a un destinatario patrio ampliado, ligeramente, por el francés dada la naturaleza coproductora de su país. Por tanto, diversos tipos de receptores para relatos diferenciados también a nivel localizador: de las veintisiete referencias que constituyen la entrada del blog, ninguna es coincidente para los tres largometrajes tratándose, únicamente, de dualidades (Nadie conoce a nadie y Noche y día comparten el haber rodado algunas de sus escenas en la Plaza de San Francisco, próxima a la Catedral; mientras que la producción norteamericana y la noruega posicionaron sus cámaras en la Plaza de Santa Marta y el coso taurino). Diferentes ubicaciones que parecen anticipar un tratamiento diversificado de la ciudad.

\section{¿Visiones distanciadas de la ciudad? Narratologías diferentes, imágenes coincidentes}

De acuerdo con lo defendido, el hecho de que las tres películas analizadas se correspondan con narratologías diversas (melodrama romántico autoral en el caso de la noruega; ciencia ficción, en el de Noche y día y thriller, en el de la nacional) invita a una suposición primigenia de que la conceptualización y el rol que le otorgan a la urbe responde a esta diferenciación latente. Y relacionado con esto, es importante tener en cuenta que solo la producción hispano-francesa se ha rodado íntegramente en el plató natural sevillano, puesto que, tanto La Joven de las naranjas como Noche y día solo dedican un porcentaje de su duración total al mismo (aunque en ambos casos más de catorce minutos aglutinan imágenes rodadas en la urbe andaluza suponiendo un 12 ' $78 \%$ del relato, en el primer caso y un 18'48\%, en el segundo); una reducción manifestante que, por el contrario, no supone una selección excluyente de las localizaciones metropolitanas y sí una diversificación espacial regida, a su vez, por intereses narrativos y genéricos.

19 En términos de diferencias, una de las identificadas en primer lugar remite a la forma en que es enunciada inicialmente la ciudad: mientras que Nadie conoce a nadie recurre al anclaje, la gradualidad caracteriza a las otras dos producciones. En el caso de la dirigida por Mateo Gil, cabe destacarse que cumple escrupulosamente con una de las tradiciones del discurso cinematográfico en su génesis global en tanto se comprende que los minutos de apertura han de posicionarlo geográficamente. Así, sus imágenes muestran a varios de los referentes metropolitanos hispalenses: mediante planos aéreos panorámicos, se suceden los puentes del V Centenario y San Telmo, la Torre del Oro, la Catedral y la Maestranza donde comienza el discurso al aparecer en su centro el cadáver de un cofrade ${ }^{24}$. Además, el rótulo "Sevilla. Viernes 14 de abril del 2000" que aparece en el [02:10] ${ }^{25} \mathrm{le}$ permite al espectador confirmar la ubicación supuesta hasta ese momento.

La estrategia planteada en Noche y día se define por aludir de forma secuenciada al país español hasta su escenificación a través de la urbe andaluza. De esta manera, hemos identificado cuatro momentos previos en los que se anticipa la reubicación territorial del relato: en el [46:58], el personaje interpretado por Tom Cruise le habla a la protagonista femenina (Cameron Díaz) de Antonio Quintana, su antagonista, y quien es definido como un "traficante de armas español"; en el [1:03:28], se presenta la llegada de otro de los personajes a la estación de trenes de Sevilla-Santa Justa identificable por uno de sus paneles informativos; mientras que en el [1:08:47], el actor Jordi Mollà, Quintana en la ficción, aparece en un patio andaluz (su reconocimiento es más complejo al presentar 
características de iluminación que lo dificultan, aunque, el empleo de una partitura con influencias arábigo-andaluzas permite su relación con España y, concretamente, con su región más sureña). Minutos después, en el [1:19:08], el anticipo informativo se confirma gracias a la frase "Nos vemos en España dentro de dos días" que encuentra a su realización espacial en el [1:25:13], momento del montaje en el que el plano aparece ocupado por la Catedral y, en su fondo, por La Giralda. De este modo, esa visión se villanocéntrica a la que aludíamos con anterioridad se mantiene vigente en la actualidad, sobre todo, en términos valorativos externos: la capital andaluza sigue ostentando su condición de representante española aunando los atributos asumidos por la ausencia de cualquier alteración temporal, continúa siendo el epíteto de lo nacional, de lo festivo, del flamenco, del entorno taurino, de la mujer morena con rasgos árabes heredera de la figura femenina descrita por Prosper Mérimée. Y, precisamente, esta suerte de reflejo del cine patrio de los años cuarenta y cincuenta encuentra su expresión en la película norteamericana al seguir al rótulo "Sevilla, Spain" el desencadenamiento de una secuencia de imágenes regida por la confusión: gigantes, cabezudos ${ }^{26}$, una banda musical que interpreta la canción de los San Fermines ${ }^{27}$ y personas ataviadas con el traje típico de esta celebración pueblan una calle central. La acción pierde significancia representativa a un doble nivel, puesto que, este tipo de reunión ciudadana es más propia de localidades rurales y lo melódico y la vestimenta apuntan a una región del norte tratándose, además, de uno de sus eventos idiosincrásicos.

El patrón reiterativo y anticipativo descrito para el largometraje de 2010 se repite en La Joven de las naranjas: las alusiones a España y Sevilla se producen en dos ocasiones antes de que la cámara materialice al escenario urbano. La primera de ellas se posiciona en el [24:23] cuando el protagonista masculino se fija en el libro sobre Francisco de Goya que está leyendo el femenino y quien le presenta como un artista nacional muy conocido ocupando el plano posterior el cuadro de La maja desnuda pintado antes de 1800. Esta elipsis alusiva, la única identificada en la primera parte del texto fílmico el cual se desarrolla en el país productor principal, es seguida por las referencias incluidas en el [38:21], cuando la metrópoli hispalense es enunciada verbalmente, y en el [38:42] al expresarse mediante una postal (recuperación de esos viajes testimoniales abordados en el primer apartado) y, específicamente, mediante una parte de la Catedral y una sección de su torre, además de identificarse las hojas de un naranjo, correlación directa con el título del largometraje. Así, al aparecer el nombre de la urbe y dada la continuidad de la narración, se comprende que el protagonista masculino se desplazará hasta la metrópoli hispalense ubicándosele en la estación de autobuses Prado San Sebastián en el [39:07] siguiendo su recorrido por otros de los enclaves fílmicos icónicos como los Jardines de Murillo, una calle del Barrio de Santa Cruz, la calle Sierpes, una de las vértebras fundamentales para el trazado urbano central, y el Patio de los Naranjos desde donde materializa a la postal recibida.

Comparando los tres casos, emerge como evidente la funcionalidad icónica que tanto la Catedral como la Giralda han asumido con el paso del tiempo. Al igual que sucede con la Torre Eiffel y París o con el Coliseo y Roma, la condición localizadora reside en sendas construcciones; son constituyentes fundamentales de la Historia de la metrópoli, protagonistas inalteradas de los souvenirs que, precisamente, anclan su rol de representantes del escenario urbano en el que habitan; son, en definitiva, expresión de Sevilla siendo identificados e identificables por cualquier individuo con plena independencia de una experiencia real en el emplazamiento metropolitano. Las tres 
producciones recurren a la imagen artística de la ciudad hispalense mantenida como sucedía con las primeras cinematográficas comprendiendo la suerte de necesidad de recurrir a estos referentes para especificarle al espectador el lugar en el que se desarrolla la acción y, en términos informativos y turísticos, concretándole qué construcciones son emblemas de su identidad.

El segundo distanciamiento existente entre los largometrajes examinados se erige en términos narrativos y funcionales. Comenzando por el que cuenta con un menor porcentaje de minutos rodados en el plató natural sevillano, Noche y día, la presentación que hace de la ciudad se caracteriza por abordar múltiples zonas. En el blog de visitasevilla.es se relacionan seis localizaciones: la Casa de Pilatos, la Plaza de Toros de la Maestranza, las plazas Nueva, de la Virgen de los Reyes y de Santa Marta y la ya mencionada estación de Santa Justa; escenarios naturales que, al trasladarlos al mapa de la ciudad, se definen por una proximidad que favorece la experiencia del relato cinematográfico por parte del espectador. Ahora bien, el tratamiento que recibe cada uno de ellos queda sumido en la acción narrativa; es decir, la Casa de Pilatos es la vivienda de Quintana, el traficante español quien, en cierta medida, no deja de representar al mito de la figura romana en tanto actúa como antagonista del protagonista persiguiendo su rendición e, incluso, muerte. Las plazas, participando de la persecución prototípica del cine de acción que tiene lugar entre los minutos [1:32:27] y [1:38:24], se convierten en no lugares, según la nomenclatura de Marc Augé28; lugares de paso que simplemente asumen una condición espectatorial ${ }^{29}$. Una irrelevancia funcional que incluso se puede defender por la ausencia de pertenencia real: una parte de las calles por las que discurren los personajes, en realidad, se encuentra en la también localidad andaluza de Cádiz ${ }^{30}$ siendo solo en momentos concretos del montaje cuando se identifican aquellos elementos constitutivos de los diferentes emplazamientos urbanos grabados en el trazado sevillano (como, por ejemplo, sucede en el [1:32:49], con el edificio de La Adriática posicionando al relato en la céntrica Avenida de la Constitución). La persecución se integra a partir del [1:33:33] en la recreación de los San Fermines al aparecer un conjunto de individuos ataviados con el traje tradicional (camisa y pantalón blancos y pañoleta roja al cuello) que corren delante de un grupo de toros. La pareja protagonista y sus antagonistas se convierten en metáforas de estas realidades imitando sus movimientos (incluso la moto en la que se desplazan Tom Cruise y Cameron Díaz emula el giro de un capote) alcanzando uno de sus puntos álgidos definidores: la entrada en el coso. Otro detalle de este fragmento es el componente musical: la partitura ejerce una función geográfica al estar compuesta con una escala arábiga, representativa de las melodías andaluzas, e interpretada, entre otros instrumentos, por unas trompetas y unas castañuelas, sonidos referenciales, acompañados de un acordeón, símbolo argentino que refuerza la inexactitud de este segmento narrativo (esto es, la asociación errónea de conceptos atribuidos al universo hispano que no siempre se corresponden con el español).

En el caso de La Joven de las naranjas, película que grabó casi el 20\% de su duración en la metrópoli española, la visión romántica que domina la trama se traslada a la concepción urbana y es que, después de enunciarse mediante los estereotipos arquitectónicos comentados, la cámara rastrea la zona centro: siguiendo los pasos de la pareja protagonizada por Harald Rosenstrøm (Jan Olav) y Annie Dahr (la joven de las naranjas), muestra al Puente de Triana, la Plaza de España, la Facultad de Bellas Artes, los jardines del Alcázar y los interiores de la Catedral y la Maestranza; iconos sevillanos que se alternan con espacios menos identificables, pero y no por ello, carentes de relevancia 
(una taberna tradicional con la barra de madera, cuadros religiosos y baldosines con formas geométricas coloristas ${ }^{31}$; una calle en el barrio de Triana; un local en el que se está bailando flamenco y un parque). La sección sevillana finaliza retrocediendo hacia sus localizaciones iniciales: los protagonistas recorren conjuntamente los Jardines de Murillo para, antes de llegar a la estación de trenes, desplazarse por la ribera del Guadalquivir, concretamente, por el Paseo Alcalde Marqués del Contadero, dejando al otro lado del río las fachadas coloridas de la Calle Betis. Merece destacarse que, a pesar del distanciamiento con Noche y día, ambas comparten la ruptura lógica con el emplazamiento urbano: si la producción norteamericana alternaba planos rodados en las zonas centro de Cádiz y Sevilla (con imágenes grabadas en las calles Placentines y otras ocupadas parcialmente por el Palacio Arzobispal, la Plaza del Triunfo, la Catedral o el Archivo de Indias); en este caso, Eva Dahr plantea saltos en tanto el joven cruza el Puente de Triana para llegar a un destino que está en los alrededores de su punto de partida. Asimismo, el largometraje noruego también recurre a música arábigo-andaluza (más específica que la presente en la banda sonora norteamericana) encargándose, de nuevo, del anclaje geográfico del film. Al mismo tiempo, deseamos matizar que, precisamente, es la producción española la que se distancia, en términos generales, de este principio al recurrir a una composición orquestal adaptada al género narrativo sin determinismo localizador alguno.

Continuando con Nadie conoce a nadie, el lienzo de juego de rol que le caracteriza se extrapola a la ciudad convirtiéndola en parte activa del evento lúdico como sus espacios religiosos lo hacen en verdaderas estaciones de penitencia (no se puede olvidar no solo que la imagen que presentan los jugadores imita a la de los cofrades, también que la propia historia, ambientada en la Semana Santa, parece criticarla a través de su trama principal) ${ }^{32}$. Pero, lo más destacable de la producción de 1999 es que en ella subyace la finalidad potenciadora del cine como herramienta turística o, al menos, de recreación del texto cinematográfico y es que, mediante la lógica del juego, el espectador conoce en todo momento los escenarios naturales que le son mostrados al recurrir a rótulos identificativos: en el [15:09] aparece el de la Iglesia de la Salvación; en el [38:31], el de la del Cautivo; en el [51:59], el de la de San Pablo; en el [1:18:29], el que identifica al Recinto de la Exposición de 1992 (específicamente, al Pabellón de la Santa Sede) y en el [1:28:38], el que ubica a la narración en la Calle Feria. A pesar de que no se establece una correlación temporal entre las enunciaciones, sí se sigue un patrón visual: todos los rótulos se insertan en planos aéreos que denotan tanto el trazado urbano sevillano como diseños arquitectónicos concretos. A su vez, estas presencias están complementadas por otras que, dada su naturaleza icónica, son identificadas y asociadas con el escenario metropolitano; entre ellas, la Catedral y su Giralda, la Torre del Oro, el Puente del Alamillo, el Archivo de Indias y varias calles del Barrio de Santa Cruz. Además, se suman otros dos elementos fundamentales: la maqueta de la ciudad que actúa como tablero del juego (remarcando así su condición participativa en el desarrollo discursivo) y el mapa sobre el que trabaja el protagonista, Simón, para resolver la partida definitiva. Esta acción, que se desarrolla entre los minutos [1:26:57] y [1:28:27], aporta diferentes datos que desvelan la génesis conformadora de la urbe: la disposición alterada de los puntos cardinales (con el norte en la izquierda), el trazado derivado del río, la continuidad en una quasi línea recta de las tres iglesias en el lienzo metropolitano y la posibilidad de unir mediante un trazo único y directo que atraviesa el centro de la ciudad a sus dos construcciones más altas (La Giralda y el Puente del Alamillo). De este modo, la película ofrece, a través de sí misma y durante todo su desarrollo, una ruta de sus localizaciones 
promoviendo, para el caso del espectador que conoce la metrópoli, una experiencia compartida de la acción en el momento en la que es narrada. Una integración que alimenta el interés de aquel que aún no la ha visitado y quien, motivado por las escenificaciones, crea mentalmente a la urbe representada. Sin embargo, la asociación entre la realidad y lo visualizado no llega a ser completa, puesto que y según revela el guion de la producción ${ }^{33}$, varios de los emplazamientos se presentan denominados falsamente: si bien las tres iglesias comentadas se ubican en las coordenadas marcadas en el mapa, sus nombres han sido modificados resultando que el edificio presentado como Iglesia de la Salvación es la del Divino Salvador; la del Cautivo, la de San Ildefonso y la de San Pablo, la de La Magdalena; alteraciones a las que se suma la localización catalogada como Calle Feria y que, en realidad, forma parte del municipio vecino de Carmona.

En definitiva, las propuestas descriptivas ofrecidas por los tres largometrajes comparten más puntos en común que diferencias entre sí: en todos los casos, la presentación de Sevilla se realiza a partir de un personaje masculino que persigue la obtención de algo o la resolución de un conflicto; los mismos emplazamientos y edificios icónicos remarcan la posición geográfica de la cámara; determinados escenarios responden a un principio falseador justificado por motivos narrativos o específicos de la producción (como los permisos de rodaje en espacios públicos) y la metrópoli asume su naturaleza de plató cinematográfico natural observando el discurrir de los diferentes relatos. Las distancias entre los textos fílmicos se derivan de sus condiciones narratológicas: el ritmo del montaje característico de la ciencia ficción, sobre todo, para el caso de las persecuciones hace acto de presencia en Noche y día sucediéndose planos rápidos en los que la urbe se erige como lienzo pasivo en el que ciudadanos y visitantes viven su cotidianidad; en La Joven de las naranjas, se convierte en testigo de la relación amorosa iniciada entre los protagonistas aportando una visión exótica y sensual en la que subyace el estereotipo romántico otorgado por la gran mayoría de las artes a la localidad sevillana; mientras que en Nadie conoce a nadie, participa pasivamente en el relato dada la conversión que los personajes hacen de sus calles y construcciones en elementos del juego de rol descrito; su propio trazado favorece su empleo como una suerte de crucigrama en el que se recompone el relato.

\section{Conclusiones: Sevilla, tradición e icono. El mantenimiento del referente colectivo}

27 La principal consideración a la que hemos llegado una vez examinados los largometrajes seleccionados es que la ciudad hispalense puede ser calificada de urbe atemporal e identificable. Las tres películas recurren al anclaje geográfico a partir de los referentes tradicionales para, después, establecer una suerte de negación: los espacios no son plenamente reconocibles por el ritmo del montaje o no son mostrados en su totalidad por la composición de los planos. En consecuencia, el espectador asume una serie de pautas iniciales que le permiten ubicar a las acciones narrativas principales para quedar relegado, minutos después, a una posición de observador participativo: la mirada fílmica se naturaliza confiándole la realidad urbana constituyente que poseen esos escenarios metropolitanos. La Catedral, las calles irregulares centrales, los patios, las zonas ajardinadas... Son integrantes innegables que no pueden ser obviados cuando es retratada por el séptimo arte, menos aún, cuando late en este ejercicio una doble función: la geográficamente referencial y la derivada del city placement defendida por Alfonso 
Méndiz; es decir, la urbe se convierte en objeto de aprovechamiento turístico y, por ende, económico mostrándose en su cotidianidad ante el público fílmico. En este sentido, también merece recuperarse el blog que ha servido como origen de este trabajo, ya que, la selección de localizaciones que ofrece parece responder al propio principio de la enunciación; lo que queremos decir es que le comunica al lector y futuro visitante una relación de escenarios naturales a los que puede acceder, en su mayoría, de forma gratuita durante sus desplazamientos. Un ofrecimiento de datos que volvemos a interpretar como asociado a los intereses económico-turísticos: la mayoría de los enclaves se encuentran per se en las áreas centrales de la metrópoli o en zonas muy próximas lo que, además de facilitar los movimientos por el trazado urbano, implica, por un lado, el acceso a otras construcciones y espacios igualmente esenciales e icónicos y, por el otro y tratándose de un efecto derivado, la inmersión en la lógica turística, en la red diseñada por comerciantes y empresarios que buscan la satisfacción del visitante a todos los niveles de lo experiencial.

Como conclusión general y a tenor de lo presentado en los diferentes apartados, Sevilla mantiene su naturaleza simbólica no solo andaluza también, española. Su identidad como una de las urbes con uno de los pasados más determinantes para la Historia nacional ligado a la coexistencia de espacios y edificaciones reflejo de diversos movimientos artísticos y épocas conceptuales la convierten en una de las localizaciones naturales por antonomasia del lienzo cinematográfico patrio. Al mismo tiempo, el ejercicio desarrollado y por el que sus atributos tradicionales se han arraigado pasando a formar parte del imaginario colectivo universal dificulta cualquier acto de separación a nivel representativo. La urbe hispalense no puede ser concebida sin su Catedral y su Giralda, sin los patios y jardines que amplían los límites de las viviendas reales, sin su musicalidad flamenca ni el sonido de sus tabernas. El cine se hace eco de esta realidad conceptual siendo incapaz de negar a los constituyentes significativos de la ciudad: Sevilla puede ser mostrada de forma parcial, condicionada por el factor temporal o por la narratología que la relata, pero, nunca podrá ser desligada de todos esos referentes que escenifican su identidad.

\section{NOTAS}

1. Juan Antonio, Díaz, "Imagen de Andalucía en los viajeros ingleses del s. XIX”, en Alberto, Egea (Coord.), Dos siglos de imagen de Andalucía, Sevilla, Centro de Estudios Andaluces, 2006, p. 89.

2. Antonia, Rey-Reguillo, "Celuloide hecho folleto turístico en el primer cine español", en Antonia, Rey-Reguillo (Coord.), Cine, imaginario y turismo: estrategias de seducción, Valencia, Tirant Lo Blanch, 2007, p. 67-68.

3. Francisco, Ayala, La Imagen de España, Madrid, Alianza Editorial, 1986, p. 31.

4. Serafín, Fanjul, Buscando a Carmen, Madrid, Siglo XXI, 2012, p. 111-129.

5. Antonia, Rey-Reguillo, op. cit., p. 69.

6. Ibíd., p. 77.

7. Ibíd., p. 78. 
8. Román, Gubern, “El cine sonoro (1930-1939)”, en Román, Gubern; José Enrique, Monterde; Julio, Pérez; Esteve, Riambau y Casimiro, Torreiro, Historia del cine español, Madrid, Cátedra, 2009, p. 157.

9. Para profundizar en el tema sobre los conceptos de españolada y españolidad en la crítica cinematográfica se recomienda el trabajo de Valeria Camporesi Para grandes y chicos. Un cine para todos los españoles. 1940-1990 (Madrid, Ediciones Turfan, 1994).

10. Begoña, Soto, "Imagen/es de España: de los primeros viajeros con imágenes a las imágenes para los primeros turistas", en Antonia, Rey-Reguillo (Coord.), Cine, imaginarios y turismo: estrategias de seducción, Valencia, Tirant Lo Blanch, 2007, p. 107.

11. Begoña, Soto, op. cit., p. 108

12. José María, Claver, Luces y rejas. Estereotipos andaluces en el cine costumbrista español (1896-1939), Sevilla, Centro de Estudios Andaluces, 2012, p. 42-45.

13. Ibíd, p. 49.

14. Antonia, Rey-Reguillo, op. cit., p. 88.

15. José Luis, Navarrete, "La españolada y Sevilla", en Cuadernos de EIHCEROA (Equipo de investigación Historia del Cine Español y sus relaciones con otras artes), no 4 , Sevilla, Padilla Libros, 2003, p. 24-25.

16. José Luis Navarrete, op. cit., p. 53-54.

17. José Luis, Navarrete, op. cit., p.26.

18. Elena del Mar, Jiménez, Turismo inducido a través del cine. Génesis del imaginario romántico de Córdoba en el contexto cinematográfico español (1920-1930) [Tesis Doctoral inédita], Madrid, Universidad Carlos III de Madrid, Departamento de Humanidades: Historia, Geografía y Arte, 2012, p. 36-37.

19. Alfonso Méndiz, "Emplazamiento de las ciudades en el cine (City placement): una estrategia de doble sentido entre la producción cinematográfica y la industria del turismo", en Actas del III Congreso Internacional Latina de Comunicación Social, 2011, p. 4.

20. Si bien ni en este caso ni en el comentado a raíz de la presentación de la Andalucía Film Commission se ofrecen recorridos sobre un mapa de la urbe, el 2 de noviembre de 2016 la edición sevillana del periódico nacional $\mathrm{ABC}$ publicaba la noticia Ruta por los escenarios de cine de Sevilla escrita por Ana Mencos y en la que, mediante un diseño digital, el lector se ubicaba de forma específica en determinadas localizaciones a partir de una o varias obras audiovisuales tanto nacionales como extranjeras (por ejemplo, el Palacio de Monsalves, edificio diseñado por Aníbal González, ha asumido actualmente la identidad de clínica privada en la serie televisiva nacional Allí abajo, suerte de adaptación invertida del largometraje Ocho apellidos vascos -Emilio Martínez Lázaro, 2014-, una de las películas españolas más taquilleras de su Historia).

21. Realmente, se trata de una coproducción tripartita en la que el orden de nacionalidades, por aportación económica y/o técnico-artística, es el siguiente: Noruega (60\%), Alemania (30\%) y España (10\%), estando representada esta última y precisamente por la productora sevillana Jaleo Films.

22. Según el blog, la producción nacional más antigua sería Belmonte (1994), largometraje dirigido por Juan Sebastián Bollaín y ambientado en el universo taurino. Su negación incluyente se explica porque el Instituto de la Cinematografía y las Artes Audiovisuales (ICAA), dependiente del Ministerio de Educación, Cultura y Deporte y encargado, entre otras funciones, de documentar todos los rodajes de producción española, no lo incluye en su catálogo impidiendo, por ende, la consulta de datos como su ficha técnica, recaudación, etc.

23. De hecho, el impacto e interés por la tipología y el género narrativo de estos largometrajes encuentran a su propia ejemplificación en el territorio español: según datos del ICAA, Nadie conoce a nadie fue el más visto con un total de 1.410 .323 espectadores, seguido de Noche y día que congregó a 978.458 personas en las salas cinematográficas; número que se reduce hasta las 130 entradas que vendió La Joven de las naranjas. 
24. Persona que sale en procesión durante la Semana Santa representando a una de las Hermandades Religiosas que rinde culto de forma pública y específica a un referente cristiano. En el caso de Sevilla, en 2017, existen 61 cofradías y más de 120 pasos (tallas representativas) que recrean la Pasión y Resurrección de Jesucristo.

25. Las alusiones numéricas presentadas de esta manera remiten a los minutos y segundos de los montajes audiovisuales consultados en relación con su duración total.

26. Disfraz típico de las fiestas populares que consiste en una prenda holgada y una cabeza de grandes dimensiones fabricada, generalmente, en cartón rígido.

27. Fiesta de Interés Turístico Internacional que se celebra anualmente y durante los primeros días de julio en Pamplona (Navarra) caracterizada por las carreras protagonizadas por toros de diferentes ganaderías.

28. Marc Augé, Non-places. Introduction to an anthropology of supermodernity, Londres, Nueva York, Verso, 1995.

29. Este término, incluido por André Gardies y Jean Bessalel en su libro 200 mots-clés de la théorie du cinéma (París, Éditions du Cerf, 1992, p. 192-193), apunta a un espectador que recibe e interpreta el relato durante su proyección gracias a dos situaciones: de inmovilidad motriz y de gran movilidad perceptiva (de sus sentidos auditivos y visuales). Lo mismo sucede con Sevilla durante estos minutos: estática, asume la acción derivada de la persecución portadora de la continuidad al relato y, al mismo tiempo, recibe a estos movimientos, sus espacios se suceden revelando su identidad constituyente.

30. Uno de los distintivos que ha permitido identificar a esta metrópoli han sido las líneas de colores azul y violeta que recorren el suelo del centro y que forman rutas ofrecidas por los organismos locales para potenciar la experiencia del visitante quien puede recrear así diferentes etapas históricas y socio-culturales.

31. Tal y como especifican los títulos de crédito finales, esta localización se corresponde con el bar El Rinconcillo, negocio fundado en 1670 que ostenta la categoría de ser el más antiguo de la ciudad hispalense. Asimismo, el otro que aparece en el segmento sevillano, Santa Marta, identificado en el fragmento [41:00-42:57], desvela un trucaje visual: ubicado en la Calle Daoiz, con una composición más propia de una plaza, los planos que se corresponden con la entrada con forma de arco ornamentado y el campanario son, en términos de ubicación, irreales, ya que, desde esa posición, las vistas solo se corresponden con la Calle Orfila.

32. Es más, esta consideración se deja patente durante los primeros minutos del montaje cuando dos de los protagonistas, Simón y Sapo (interpretados por Eduardo Noriega y Jordi Mollà, respectivamente), abordan el tema de la Semana Santa adjetivándolo con términos como "lamentable", "horterada" o "esperpento" y ligado a figuras como los "capillitas", concepto más coloquial sinónimo de "cofrade". Por tanto, una suerte de crítica socio-cultural e, incluso, cristiana.

33. Mateo Gil, Nadie conoce a nadie. Guion cinematográfico de Mateo Gil, Madrid, Ocho y Medio, 2000.

\section{RESÚMENES}

Sevilla es una de las ciudades españolas del sur peninsular que mayor turismo nacional y extranjero atrae. Con un diseño urbanístico y arquitectónico definido por la coexistencia de estilos, se ha convertido en una localización natural cinematográfica destacada. El turismo 
surgido a raíz de este arte ha motivado la proliferación de secciones dedicadas a la presentación de recorridos y escenarios metropolitanos fílmicos incluidos en las páginas webs oficiales de urbes como París, Roma o la propia hispalense siendo este el germen de este artículo: mediante el análisis de las tres producciones más referenciadas en visitasevilla.es, perseguimos descubrir qué Sevilla es mostrada, así como, la función que la metrópoli ejerce en el relato y la relación que establece con los diferentes personajes.

Séville est une des villes espagnoles du sud de la péninsule ibérique qui attire le plus le tourisme national et étranger. Avec une conception urbaine et architecturale où coexistent des styles différents, elle est devenue un plateau de tournage incontournable dans l'industrie touristique. Nombreuses sont les sections dédiées à la présentation de parcours et de sets métropolitains filmés sur les sites web officiels des grandes villes comme Paris, Rome ou Séville. Ceci fait l'objet de cet article : à travers l'analyse des trois longs métrages les plus référencés dans visitasevilla.es, on cherche à découvrir quelle Séville est représentée, quel rôle joue la métropole sévillane dans ce récit et quelle relation entretient-elle avec les différents personnages.

\section{ÍNDICE}

Mots-clés: ville, cinéma, représentation, stéréotypes, tourisme

Palabras claves: ciudad, cine, representación, estereotipos, turismo

\section{AUTORES}

\section{MÓNICA TOVAR VICENTE}

Universidad Complutense de Madrid

\section{MARÍA JOSÉ BOGAS RÍOS}

Universidad Complutense de Madrid 